\title{
Upgrading Slum Area, Development and Hidden Inequality (Case Study: Kampung Warna-Warni and Kampung Tridi)
}

\author{
Faqih Alfian ${ }^{1}$ and Taufik Akbar ${ }^{2}$ \\ ${ }^{1}$ Program Studi Ilmu Politik, Pusat Kajian Perubahan Lingkungan, Universitas Brawijaya Malang \\ ${ }^{2}$ Program Studi Ilmu Politik, Pusat Pengkajian Kebijakan Sosial, Universitas Brawijaya Malang \\ alfaqih99@ub.ac.id
}

\begin{abstract}
ABSTRAK
Kawasan kumuh telah menjadi salah satu permasalahan dalam kehidupan perkotaan. Hal ini secara otomatis muncul akibat dari proses urbanisasi dan pembangunan. Banyak penduduk yang menempati ruang-ruang bukan lahan hunian akibat keterbataasan akses mereka. Dilihat dari prespektif teori akses, maka bagaimana masyarakat bermukim di wilayah tersebut merupakan bentuk hak mereka dalam memanfaatkan sumber daya alam. Pemanfaatan tersebut mereka pergunakan salah satunya sebagai lokasi tempat tinggal. Penelitian ini menggunakan metode kualitatif deskriptif, dengan mengambil beberapa sampel sebagai sumber wawancara. Penataan kawasan kumuh sekarang beranjak pada dimensi yang lain, dimana bukanlah lagi pada penggusuran paksa, namun bagaimana menata dan merubah kawasan permukiman tersebut menjadi layak huni. Ada beberapa indikator yang dipakai dalam melihat suatu kawasan hunian dikatakan tidak layak huni. Upgrading slum areas tersebut telah mampu merubah kawasan yang dahulunya tidak layak menjadi lebih baik dan mampu untuk memenuhi indikator akan kelayakan kawasan permukiman pada umumnya. Langkah tersebut juga merupakan bagaimana masyarakat tetap berupaya untuk dapat mendapatkan akses pada wilayah tersebut. Kampung Jodipan dan Kampung Tridi berubah penampilannya, dan meningkatkan kualitas lingkungan tinggal mereka menjadi semakin rapi, bersih serta akses pelayanan publik yang terjangkau. Penelitian ini masih menyisakan beberapa permasalahan, salah satunya ketidakpastiaan akan hak atas lahan sehingga mereka tidak mengetahui masa depan dari kawasan yang mereka tempati sekarang. Jaminan atas kepemilikan lahan ini menjadi sesuatu yang penting untuk memperjuangkan kesetaraan hak atas pelayanan negara, pengakuan negara, serta hak tinggal di dalam kawasan.
\end{abstract}

Kata Kunci: Kawasan kumuh, pembangunan, toeri akses, upgrading slum areas, inequality, secure tenur

\section{ABSTRACT}

The existence of injustice and inequality in access to the development results of the city. Slum areas have become one of the problems that exist in urban life. This automatically occurs as a result of a normal process called urbanization and development. Where many residents end up occupying non-residential areas due to their limited access. Seeing from the perspective of the access theory, how people live in the area is a form of their right to be able to utilize natural resources. One of these uses is used as a place to live. This study used a qualitative descriptive method, by taking several samples as a source of interviews. The arrangement of the slum area is now moving to another dimension, which is no longer forced evictions, but how to organize and change the residential area to be habitable. There are several indicators used in seeing a residential area which is said to be unfit for habitation. Upgrading slum areas has been able to change areas that were previously unfit to be better and able to meet indicators of the feasibility of residential areas in general. This step is also how the community continues 
to strive to gain access to the area. Kampung Jodipan and Kampung Tridi have changed their appearance, and have improved the quality of their living environment, with a tidier, cleaner and more affordable access to public services. Apart from the results of this research, there are still some problems, one of which is the uncertainty of land rights, so that they will not know the future of the area they live in now. The guarantee of land ownership is important to fight for equal rights to state services, state recognition, and the right to live in the area.

Keywords: Slum areas, development, theory of access, upgrading slum areas, inequality, secure tenure

\section{Introduction}

Poverty is a social pathology that until now has become homework for every stakeholder. One reason for the high rate of poverty is structural social inequality and the limited opportunities or opportunities for the wider community to get equal access control over resources tends to be dominated by a few people or certain groups (oligarchy) (Syawie, 2011). The acute problem shows that the seriousness of the stakeholders on the question of the poor is questioned. Their alignment with the poor is not proportional to the level of accessibility of the community in obtaining and managing resources. Often these socio-economic inequalities and inequalities are faced by rural communities. They find it difficult to get decent jobs, access to services and management of resources is very minimal, and bring them to acute poverty (Davis, 2006). As a result, the perceptions of the village community to make their lives better and prosperous than living in the village, they tried their luck by moving to the city. This perception of the city brings the view that with their move to the city they get decent workshops and are able to improve the economy of the family in the village. However, in fact, the process known as urbanization does not always have a positive impact as they imagined before leaving for the city.

The city began to have an attraction for rural communities to improve their welfare by finding decent jobs rather than work in the village. In looking at this urbanization process, their views on the city were also tracked and understood so as to give their picture and hope when they were living in the city. Some things that are expected and perceived by the village community over the city are economic access that can help them improve their economy. It is not uncommon for villagers to begin building houses in certain areas, for example, on the outskirts of the railroad tracks, river banks, or places that are actually not suitable for habitation. They built a house around it because of the lack of money brought or renting a house, which in fact is difficult to reach a relatively high price. As a result, with sufficient capital, they built a house that for them was enough for a place to rest and settle with the number of families there. The settlements they occupy are actually forbidden to be suitable housing; closer atmosphere and slum environment; and prone to disasters and evictions when the local government wants to normalize the slums. For the government, slums should not be made as settlements because they can affect workers in the people who live there. However, the large process of urbanization, the lack of policies that can limit the pace of population movements, and the failure of the government to improve the welfare of rural communities, resulting in their desire to seek new social life in urban areas. This has an impact on increasing slum areas in a number of major cities in Indonesia. 
One of the cities that are the destination of urbanization is Malang City. Malang City is a city that has a rapid pace of development after the city of Surabaya. This is because the city of Malang is an education city with a large number of universities, a city that is designed as the center of culture and tourism. It is not imagined if the community starts visiting the city as an effort to increase their income and economy. However, the arrival of residents to this city is not supported by the existence of suitable land and space for their residence. Most of these migrants find it difficult to find a place to live because the value of renting a house is not worth the money they have. In the city of Malang itself, there are several characteristics of the settlements that are occupied, among others: Dutch colonial settlements, village areas, real estate areas, residential areas in hinterland wilayah, high-rise areas, military areas, and slum areas (Santoso, 2016). By looking at the characteristics of the business, the migrants occupy many slum areas because there is no place that they can reach and become their last resort to try their luck in urban areas.

The existence of slums, which usually occupy space on the outskirts of the city, is inevitable and becomes a problem that must be resolved by the stakeholders. Moreover, Malang City is one of the cities that has a high number of slums in East Java, with a number spread in 29 urban villages from 57 in Malang City. The local government may have carried out a strategy - usually leading to eviction - to fix and organize slums in Malang City. However, the government's strategy is not always able to completely eliminate slums in urban areas. Even though their residence was evicted, these migrants will continue to look for other places to continue their lives even though they will later face the risk of being evicted. They will move from place to place, looking for space to live in, even though the place has been banned by the local government. The dynamics of the lives of immigrants and slum settlements is due to the lack of strict control from the government, which has triggered over-urbanization and under ruralization, which shows the real social and economic inequality between villages and cities (Harahap, 2013).

The issue of slum settlements can be seen from the extent to which proper facilities, for example, access to clean water, access to sanitation and hygiene, adequate housing and space for occupation, and certainty over land ownership. Most of the settlements occupied by migrants are minimal from some of the accesses mentioned above. In other words, the migrants do not have a view and the shadow of where they will live and only rely on space that is actually not intended as a residential area. However, this must be done for the sake of their survival even though they occupy slum areas, such as river banks and the edges of railroads. The government's perception of slums is an area that has been regulated to not be occupied as a proper dwelling and will act decisively when there are settlements standing because it is not in accordance with the Spatial and Regional Spaces (RTRW). On the other hand, the government is of the view that slums are very bad for the people, close to criminal acts and need to be normalized so as not to bring the impact of labor to the beauty of local city governance. However, this does not take place in slums in Malang City, which have slums that have been turned into beautiful areas and suitable for tourism.

Jodipan Tourism Village (Kampung Warna-Warni) and Tridi Kesatrian Village (Kampung Tridi) are slum settlements in Malang which have recently become tourist destinations. Initially slum settlements due to being on the banks of the river and under the railroad bridge have been converted into thematic villages by a group of students working at the University of Muhammadiyah Malang, who work with the government and private parties, which are carried out independently by local communities and students. The two regions were changed so that they were no longer impressed with the slums by providing aesthetic art of colorful paint so that it did not appear to be a bleak and decent 
area for the inhabitants of the community. What has been done by real work groups from these students has succeeded in making a significant impact on the local community, so that they can lift their economy after this place has a tourist attraction. Therefore, Jodipan and Kesatrian are alternative areas for visitors who want to travel to Malang City. This has indirectly helped the welfare of local people who have lived in slums and are vulnerable to disasters.

The two slum area cases in Malang City are interesting to study considering the slum upgrading process has an impact on the level of welfare of the local community. In addition, after upgrading the slum this area also had an impact on the accessibility of clean water, sanitation and hygiene, and habitable settlements for the local community. However, there are problems that are still problems regarding their living space on the banks of the river, namely certainty or land rights. Most of the land occupied is not in accordance with the RTRW of Malang City government. By looking at the criteria described above, the Jodipan and Kesatrian villages can only be called habitable settlements with upgrading processes that indirectly change the views of the wider community about slums, but what about the issue of rights to land or land. How does the government provide access to residents of the area to improve their economic welfare after upgrading the slum area.

\section{Literature Review}

\subsection{Urban Politic}

Cities are social areas resulting from the production of social spaces and capital production. The production of space created as a result of the accumulation of capitals makes the city created by various kinds of interests from various groups (Lefebre, 2000). There are conceptual three according to Lefebre (2000) which explain how social space is formed, namely: (1) lived space, social space in which every member is involved who has a relationship or relationship to ownership over space. (2) conceived space, a space formed from the conception of people or some people on how space is conceptualized in general. (3) perceived space, space becomes something specifically perceived by individuals, groups or society.

In looking at urban dynamics, the analysis cannot be separated from the influence of each regime in urban development. Furthermore, if we look at the city, we certainly cannot be separated from the existing regimes and how they affect urban development. David Judge, in his book Theory of Urban Politics, that in the study of urban politics will be faced with the dynamics of the development of theory, starting from the theory of pluralism, where according to him there are no minority and majority groups, all the same, and can contribute to urban development. Second, is the elite theory, where the development of urban dynamics is only regulated and controlled by a small group of rulers both in the system of government and economics. The last is the regime theory, where political organizations make decisions about urban dynamics. There is a growth machine that sees that urban development is not the result of politics, but rather the dynamics of economic development controlled by economic elite groups. Where they

control almost overall economic resources. So the assumption is that cities become a battleground for economic interests which cannot be controlled by most people (Judge et al., 1995). 


\subsection{Theory of Access}

To understand the dynamics of communities in slum or illegal areas, we look at one of them with the access approach. Access itself is the ability to benefit from something (material, other people, institutions and symbols) (Ribot, 2003). As an example of how a person is able to benefit from sunberdaya regardless of whether there is a property relationship (right).

In this concept, we can be facilitated to conduct analysis related to who will use (and not take advantage of) something, in what way, and when (in what kind of situation). Looking at the problem of resource conflicts, such as in the context of the river area as a residential area. In the context of access, where the ability to obtain benefits from resources (DAS) is mediated by the boundaries that have been set in the context of the political economy and cultural framework when this search for access takes place. This has resulted in what is known as a "structural and interconnected access mechanism". Apart from the resource access mechanism, there are several other access mechanisms, namely: 1) Access to technology, most resources can only be extracted using technology; those who have access to higher technology will benefit more than those who do not. 2) Access to capital, this access is often referred to as access to wealth in the form of finance and equipment. Access to capital / capital can be used to control or maintain access to resources. 3) Market access, market access can be seen as the ability of individuals or groups to obtain, control, or maintain exchange gates. 4) Labor access, labor scarcity and surplus are able to affect the portion of the relationship in obtaining resource benefits that can be enjoyed by anyone who is able to control workers. 5) Access to knowledge, discourse and ability to enhance terminology greatly affects the overall framework for access to resources. For example, discussions on "global equality (global company)" by international NGOs and other actors create universal categories and teach them around the world in the name of environmental protection. 6) Access to authority, individuals or institutions that have privileges with the authority to make and implement laws will greatly affect who will benefit from the resources. 7) Social identity access, social identity-based access mechanisms also influence and are influenced by the market and labor access mechanisms as well as rights-based access. 8) Access to social relations, access through negotiation of social relations such as friendship, mutual trust, reciprocity, patronage, dependence, and obligation are critical points in the access network.

\subsection{Slum Area}

In describing the slum area, it will use several indicators that are conceived by the United Nations, where they interpret slum areas as a residential area that is very minimal; first, proper and strong housing and resistance to various changes climate. Second, the adequacy of living space in the house. Third, it is easy and inexpensive to get access to clean water. Fourth, the availability and feasibility of sanitation both public and private. Fifth, a guarantee of land to prevent eviction. The concept described by the UN above is a benchmark to determine the extent to which a settlement can be said to be uninhabitable. Through the concepts and indicators of the United Nations, this research will focus on indicators that will be used to see how the Malang City government has provided shelter or settlements that are appropriate for the population or not.

Departing from the MDG designed by the National Examination, in it, there are indicators of community welfare. In it, there is one indicator of settlement, where it also 
becomes an assessment that settlements are feasible or not feasible. There are five settlement indicators that are used to assess a residential area, namely:

1. Access to improved water, where a settlement must have access to clean water at an affordable price to meet family members.

2. Access to improved sanitation, sanitation channels must be in the settlement, and not pollute the environment, and be able to meet the needs of all family members.

3. Sufficient living area, a residential area should not be too dense and enough land is available. Likewise for building houses, where per room/room must be less than 3 people who inhabit.

4. Structural quality/durability of dwelling, residential buildings must be built with proper resilience and not in disaster-prone areas.

5. Security of tenure, which is meant in this indicator is the certainty of ownership of residential land.

\section{Discussion}

\subsection{Social and Economic Condition of Malang City}

Malang City is located at a location that is quite high at 440 - 667 meters above sea level. Malang City is located in the Brantas Groundwater Basin (CAT). In the Brantas CAT contains potential and groundwater reserves of very good quality for drinking water raw materials. This CAT Brantas area has the largest basin area in East Java Province. Meanwhile, the surface waters are in the form of streams of several rivers that function as raw material for irrigation as well as for final drainage from urban drainage. The area of Malang City is 11,055.66 $\mathrm{Ha}$, the largest land use is organized settlements of approximately 3,966.66 Ha or 36\% of the total area of Malang City (total area of settlements covering $4558.44 \mathrm{Ha}$ ). The second largest use of land is for dry land/moorland with an area of 2,654.17 ha or 24\% of the total area.

The location of Malang City which is greatly benefited because it is located in a mountainous slope, Malang City has the potential to have disaster-prone areas. This level of vulnerability to disasters is a characteristic of the area that has a sloped area with a river flow that is surrounded by river cliffs, and the slope of the land that has the potential for erosion or landslides. The potential of the region with such characteristics, of course, will greatly influence the regional burden to manage erosion-prone areas and landslides. Along with the development of the region and population growth, the other potential is to utilize the river flow area as a drainage channel and the final destination of runoff and runoff. The consequences that arise are the carrying of rubbish and erosion materials into the flow so that it has the potential to clog the drainage holes and drainage channels which in turn will cause inundation during the rainy season. The more solid piles of garbage and also waste material at certain drainage points/drainage channels, the more capacity of rainwater that will overflow and stagnate in the area. The more expensive the price of land, the lower income people will live in groups in the marginal area on the banks of the river banks.

The area, besides being an area that is still affordable in terms of price, is also a more affordable area for them, for example, the transportation of households that are close enough and do not require additional installations that are complicated and high cost. The utilization of riverbanks with cliffs that are quite high as residential areas will save the lives of the people living in the area (RPJMD Malang City, 2013-2018). 
Based on the data released by the Central Bureau of Statistics, the population of Malang City continues to increase every year. The population of Malang City from 2015 to 2017 is 2015 as many as 851,298 while in 2016 there are 859,410. The population which is actually the target of development needs to be taken seriously by the government by measuring the level or indicators that already exist. When viewed from the Community Development Index (HDI), Malang City has, if compared to East Java HDI, the value of the HDI of Malang City from year to year is always increasing and still above the East Java HDI. The HDI of Malang City in 2013 was 78.78, while the East Java HDI was 73.54 (BPS East Java, 2017). Meanwhile, to see equitable development in Malang City, one of the economic indicators is the Gini Coefficient. If Malang City is seen from the Gini Coefficient, then the Gini Coefficient Index for East Java Province in 2017 is 0.4, while the Gini Ratio of Malang City in 2017 is 0.36 . This has become a serious imbalance for the City of Malang and East Java. In general, the ratio of urban areas from 2009-2012 is higher than in rural areas. In the past four years, the ratio of urban areas is in the moderate category, while the ratio of rural areas in the low category (Yozza, 2013).

\subsection{From Slum Area to Tourism and Management Villages in Slum Areas}

The dynamics of social and economic life in slums can be understood from the extent to which the surrounding communities and other parties involved, especially the government, in providing perceptions about slums. For the government, the area which occupies most of the space along the river is used as housing by migrants who should not be converted into settlements. This is because it can lead to disasters and give a bad impression of urban governance. In addition, the term slum has a negative connotation, for example, a place that implicitly shows a view where the place is dirty, polluted, or dirty. Whereas, for the people who come from the village, they assume that there is no other place other than filling the existing space even on the outskirts of the city with enough capital to build decent housing for them. This view is not accompanied by the readiness of the government to anticipate large urbanization, where rural communities begin to move to the city along with their perception that the city is a place to find work and improve their economy.

The lack of decent space or land from the government to be approved by migrants also contributes to the establishment of slums in urban areas. What is happening in Malang City is one that needs to be improved so that slums can be a decent place to live in. By regulating slum policies also improving policies on urban and spatial governance, the government can provide good services and access to the compilation of rural communities starting to move to cities to find work. The Jodipan and Kesatrian villages became settlements occupied by the compilation community, they came to Malang City to look for other economic sources, which could support them in the village. The reason they came to the city was not located because of social and economic differences and the government's attitude in seeing the community related to their welfare improvement.

Residents in slum settlements usually have no other choice but to survive with the environmental conditions they occupy. They begin to "recognize" their own place, creatively and innovatively with their own way of living in a slum and forbidden environment. Their life experience becomes knowledge to overcome problems related to disasters and environmental conditions that begin to deteriorate. In other words, their experience and knowledge of slums are one of their ways to stay and survive even though their homes are forbidden and uninhabitable. Therefore, they remain in slums because, on the other hand, there is a sense of community and a sense of belonging between families, so they are reluctant to move. Entanglement and feelings of belonging also have 
an impact on their reluctance to move and survive on land that is actually not feasible by the government.

Jodipan and Kesatrian villages are areas with a number of slum and dense settlements. The area known as the black area is located on the banks of this river is an area of wild occupancy along the river and in its rules is not allowed to become a residential area. The condition of uninhabitable villages is caused by many things, including poor sanitation, large amounts of waste that cannot be processed, and inadequate infrastructure development. Nevertheless, the two regions have turned into tourist villages or color thematic themes which have become tourist icons in Malang City. This village is the result of the initiation of the KKN University of Muhammadiyah Malang students who initially saw the condition of this area as a very poor and considered a wild dwelling. Jodipan and Kesatrian Villages are no longer considered as slum residential areas but beautiful villages with various kinds of creativity from the local community. The two areas are also able to attract visitors, at least every day no less than 400 visitors visit. Even if it's a weekend or holiday, visitors can reach 800 people.

What has happened in the two villages has triggered the Malang City government to manage the slums. The existence of slums is an accumulation of the inability of the community to maintain their homes and their environment, as well as the government's inability to manage residential areas and provide basic facilities and infrastructure. The root of the problem with the existence of slums is the unavailability of land. The unavailability of land is a result of the imbalance of development between villages and cities so that cities are considered by the community as a dream for a better life. The Malang city government together with a team from the Directorate General of Cipta Karya and Malang City Bappeda made a program plan, and proposed activities in the priority areas for handling slums in Malang City in 2015 which consisted of three regions, Sukun, Tulusrejo and Kotalama.

\subsection{Legal Status and Certainty of the Jodipan and Kesatrian Communities}

In seeing a city, Lefebre (2000) sees the city not only as a spatial part, but also socially in accordance with the perceptions and conceptions that have been produced. Communities perceive their lives in the part of their residence, it is necessary to explore some things about the feasibility of life. Changes in the existing slum settlement areas in the Jodipan area are shown in table 1.

Table 1. The Changes after Upgrading

\begin{tabular}{|c|c|c|}
\hline & Before Upgrading & After Upgrading \\
\hline $\begin{array}{l}\text { Access to Improve } \\
\text { Water }\end{array}$ & $\begin{array}{l}\text { - The community uses water } \\
\text { purchased at retail and river } \\
\text { water to fulfill their daily needs }\end{array}$ & $\begin{array}{l}\text { - The water network from the } \\
\text { government (PDAM) has entered and } \\
\text { the community no longer uses water } \\
\text { from the river }\end{array}$ \\
\hline $\begin{array}{l}\text { Access to Improve } \\
\text { Sanitation }\end{array}$ & $\begin{array}{l}\text { - In the absence of an adequate } \\
\text { sanitation system, the use of } \\
\text { rivers is still large in the } \\
\text { sanitation system }\end{array}$ & $\begin{array}{l}\text { - Sanitation of each house has been } \\
\text { made. Improvement is still needed, } \\
\text { especially in IPAL (waste treatment } \\
\text { plant) }\end{array}$ \\
\hline $\begin{array}{l}\text { Structural quality/ } \\
\text { durability of housing }\end{array}$ & $\begin{array}{l}\text { - The majority of shelters are built } \\
\text { with wooden frames and with } \\
\text { insufficient capacity. }\end{array}$ & $\begin{array}{l}\text { - Several buildings have been } \\
\text { rearranged with reinforced } \\
\text { foundations and further beautification } \\
\text { on the exterior (tourist village) }\end{array}$ \\
\hline
\end{tabular}




\begin{tabular}{lll}
$\begin{array}{l}\text { Sufficient Living } \\
\text { Space }\end{array}$ & $\begin{array}{l}\text { - The residential area is very } \\
\text { dense, often one dwelling is } \\
\text { occupied by two families (more } \\
\text { than } 6 \text { people) }\end{array}$ & $\begin{array}{c}\text { The residential area is still in the dense } \\
\text { but decent category with 3-6 people in } \\
\text { each dwelling }\end{array}$ \\
\hline Security Tenure & $\begin{array}{ll}\text { - The area is owned by PT KAI } \\
\text { (state). Where the designation is } \\
\text { not for occupancy }\end{array}$ & $\begin{array}{l}\text { Until now, the community has not } \\
\text { received rights to the area, but on the } \\
\text { one hand they have been } \\
\text { administratively recorded in the } \\
\text { Jodipan village of Malang City }\end{array}$
\end{tabular}

The MDG indicator see the feasibility of life in a city by looking at 5 things: (1) Access to improved water, the community of Jodipan and Kesatrian Districts have two ways to access clean water. The first way is to subscribe to PDAMs for people who have sufficient income. For people with mediocre economic conditions, they access clean water needs by fertilizing wells and also drilling on the ground. (2) Access to improved sanitation, sanitation is actually already available in residential areas but there is no installation of waste management (WWTP). Household waste is still thrown into rivers and has the potential to pollute the environment. (3) Sufficient living area, based on observations in the field, residential areas in the two regions are indeed sufficient for the population, although it is still in a feasible indicator with 3-6 people in each dwelling. (4) Structural quality/durability of dwelling, ideally, a residential building must be built with proper resilience and not in a disaster-prone area. This has not been fulfilled by the two regions. The existence of buildings in commensurate rivers causes the area to be a vulnerable area for disasters such as floods and landslides. Although unprecedented, and floods are also still in fair status, anticipation, and response before a disaster occurs must still be carried out. (5) Security of tenure, in terms of territory, both regions are included in government-owned areas and PT. KAI, which is not planned for housing. So that the residents of the area do not have the legality of the land they occupy. The status of land that does not have legality is certainly very vulnerable to conflict.

The existence of thematic villages in the two regions will have a huge impact on regional income and tourism. Besides the economic impact, there is also a populist effect for the government because it is considered to have succeeded in changing the face of the slums of the city. So that various awards and community satisfaction on the government's performance will increase. Therefore, the realization of cities without slums is a big goal mandated in the RPJPN 2005-2025. The quality of decent and healthy settlements must have access to drinking water, sanitation and other basic rights (Ciptakarya, 2015). The government targets things that might be a little unrealistic, wherein the next five years, according to what is stated in the 2015-2019 RPJMN, settlement infrastructure development is aimed at realizing increased population access to quality residential environments, increasing access to proper drinking water and sanitation into $100 \%$, and realize a city without slums in Indonesia in 2019. The target is called "Program 100-0$100 "$ in the field of Settlements.

The main focus of what is done is to identify and find the root of the problem, then find the best solution, and in the end, when one problem is over, there will be an effort to look for other problems. from there we will never know, what great potential can be developed from the region. Poverty and urban slum environments are not only technical problems but rather are multidimensional problems. Not only in economic terms, but also in terms of social politics. The failure of the technocratic development paradigm in some countries must be learned because many countries fail even though the design is considered very innovative, but the development has tremendous dependency because 
its planning is technocratic and does not encourage public participation (Chernea, 1988: 458). The program target of Malang municipal government is to free the city from slums, in accordance with regional regulation No. 13 of 2014. With the program, the Malang city government tries to create habitable settlements, with better quality infrastructure services and integrated social development, economy, and culture.

\section{Conclusion}

Slums in the villages of Jodipan and Kesatrian slowly began to turn into more beautiful dwellings. With the initiation of the academics, the community, and the private sector, the two villages turned into thematic villages with colorful nuances and 3D murals. Upgrading the slum area in the two regions turned out there was still homework to be completed. The feasibility of a building that stands around the banks of the Brantas river is not yet known. Likewise with sanitation facilities and WWTPs that have not met the feasibility standard. And the most important thing is the legal status of the land of the area that has not become the property of its inhabitants. This is very vulnerable because the clarity is related to their fate and their children in the future. With the unclear legal status of the land, there is no guarantee for them regarding their future.

The Malang City Government should be more responsive about slum areas in Malang. The process of changing slums into a housing that is more feasible and humane in accordance with the mandate of the Act is still running in accordance with community initiation. And the success of upgrading the slum area in some of these areas is even claimed as the success of the City government in making thematic villages as a new alternative to Malang's tourist destinations. For the legal status and legality of community land, there has also been no further discussion.

\section{References}

Alan Harding, 1995, "Elite Theory and Growth Machine" in David Judge, Gerry Stoker, and Harold Wolman, Theories of Urban Politics, London: Sage Publication.

Cernea, Michael M.. 1988. Mengutamakan Manusia di dalam pembangunan :variabelvariabel sosiologi di dalam pembangunan pedesaan. Jakarta : UI Press.

Ciptakarya. 2015. Indonesia Menuju Zero Slum dan Zero Problem. Buletin Cipta Karya Edisi 04/tahunXIII/April.

Davis, Mike, 2006, Planet of Sum, London, Verso

Harahap, Fitri R, 2013, Dampak Urbanisasi Bagi Perkembangan Kota di Indonesia, Jurnal Society Vol. 1 No.1, Universitas Bangka Belitung.

Lefebvre, Henri, 2000, The Production of Space, Georgetown University Press: NY.

Ribot, J, C. \& Peluso, N, L. 2003, A Theory of Access, Rural Sociology

Santoso, Endratno Budi, 2016, Faktor Penentu Bertempat Tinggal Pada Kawasan Kumuh Di Kota Malang Berdasarkan Teori Doxiadis, Jurnal Tata Loka Vol. 18 No. 4 Universitas Diponegoro.

Syawie, Mochamad, 2011, Kemiskinan dan Kesenjangan Sosial, Jurnal Sosio Informa Vol. 16 No. 03, Kementrian Sosial.

Yozza Amita Elwana dkk. 2013. "Analisis Kesenjangan Daerah dan Konvergensi PDRB Perkapita Kabupaten/Kota Jawa Timur Sebelum dan Sesudah Desentralisasi". Jurnal Media Trend. Vol. 08. No. 02 Universitas Trunojoyo.

Rencana Pembangunan Jangka Menengah Daerah Kota Malang Tahun 2013 - 2018.

BPS Provinsi Jawa Timur.

Kota Malang dalam Angka Tahun 2017 